\title{
Narcissism and German Extremism in Kleist's Penthesilea
}

\author{
Hansgerd Delbrück
}

\author{
... For I were mad, \\ That you must grant yourselves, did I not try \\ Everything possible to gain my end. \\ -Penthesilea \\ Penthesilea is a bit over the top, isn't she? \\ -Gordon Anderson ${ }^{1}$
}

Written in 1807 and set against the background of the Trojan War, Penthesilea features the war of the Amazons against the Greeks and, at its centre, the battle of love between the Amazon queen Penthesilea and the Greek king Achilles. As the customs of the Amazons and the Greeks are fundamentally incompatible-in the words of Odysseus, as likely to mix as fire and water ${ }^{2}$ - the protagonists appear destined for tragedy from the very start. Even as the play begins they are engaged in combat despite having fallen in love with each other; and it ends with Penthesilea, in a fit of insane rage, attacking the lightly armed Achilles with an array of bloodhounds and elephants, tearing him to pieces and, once she has come to her senses, committing suicide to atone for her crime. The tragedy is relentless in its brutality, driven to the utmost extreme of its genre. But it is also full of soft Romantic ${ }^{3}$ ideals, and this

\footnotetext{
${ }^{1}$ Gordon Anderson is Professor of Law at Victoria University of Wellington. This essay is dedicated to him.

${ }^{2}$ Heinrich von Kleist, Penthesilea: A Tragedy, trans. Humphry Trevelyan, in Five German Plays, ed. Eric Bentley (New York: Doubleday, 1959), 318. Quotations from Penthesilea are taken from this edition and referenced by bracketed page numbers, followed by square-bracketed line numbers from Heinrich von Kleist, Sämtliche Werke und Briefe, vol. 2, ed. Ilse-Marie Barth and Hinrich C. Seeba (Frankfurt am Main: Deutscher Klassiker Verlag, 1987): [lines 125-28].

3 On Kleist's Romantic discourse see Walter Hinderer, "Seinsausstand als Lebensfeier: Anmerkungen zu Heinrich von Kleists romantischer Todesauffassung," in Sterben und Tod bei Heinrich von Kleist und in seinem
} 
combination has sometimes prompted the comment from my students that only a German could have written it, or more precisely, only one of those Germans who believed in the extremist ideals which were to culminate in the racist experiment of the Third Reich. In Penthesilea, Kleist drew from one of the most radical political experiments encapsulated in Greek mythology: here, women belong to a separate race that does its utmost to save itself from being stained by any contact with the inferior male "race." While the Amazons, a people of female warriors living in a state entirely without men, do not go so far as wanting to exterminate all men, they regularly embroil other nations in violent combat for the sole purpose of capturing their male warriors and exploiting them as a means of reproduction of their race. For a long time the Germans themselves did not feel at all comfortable with Kleist's new kind of tragedy and heavily criticised him for it. Goethe, to whom he had sent a copy of a journal containing excerpts from the play, was shocked by what he read, and believed that Kleist must have been out of his mind to write such an outrageous tragedy. In a letter to Kleist, he wrote that Penthesilea was of too miraculous a race and moved in too strange a world for him to befriend her, ${ }^{4}$ divested of its polite form, Goethe's comment clearly denounces Penthesilea as belonging to a foreign rather than miraculous race, foreign to the world of civilisation. The play had to wait nearly seventy years for its first stage production, in the Berlin Royal Theatre, in 1876, and it was another sixteen years before it was produced unabridged, in the Munich Court Theatre, in $1892 .^{5}$ A breakthrough only came at the beginning of the twentieth century, with productions by famous directors such as Paul Lindau und Max Reinhardt. After it had taken so long for it to reach the stage, the play finally appeared to be well-placed for a long-run success, and that prospect has certainly been confirmed by its recent stage history: in 1999, for example, Germany saw at least four different productions, in Munich, Tübingen, Ludwigsburg and Cologne.

historischen Kontext, ed. Dietrich von Engelhardt et al. (Würzburg: Königshausen und Neumann, 2006), 79-100.

${ }^{4}$ Goethe's letter to Kleist of 1 February 1808 is quoted in Kleist, Sämtliche Werke und Briefe, vol. 2, 694.

5 William C. Reeve, Kleist on stage, 1804-1987 (Montreal: McGill-Queen's University Press, 1993), 81. 
During the Third Reich, however, when one would have expected the play to reach the peak of its fame in Germany, there was a curious setback. The Nazis celebrated Kleist as one of the most authentically German of playwrights, but they were not interested in exploiting the war between the Amazons and the Greeks for their propaganda, unlike the battle between the Germanic tribes and the Romans in Die Hermannsschlacht-The Battle of Hermann - , written by Kleist one year after Penthesilea to inflame German patriotism against Napoleon; productions of Penthesilea in the Third Reich were a labour of duty rather than love. ${ }^{6}$ This is rather surprising in view of the particular values which Kleist embodies in the mythological society of the Amazons: whereas his Greek heroes display a firm belief in clarity, rationality and logical consistency as the indispensable foundations of advanced humanity and civilisation, the customs of the Amazons suggest the ideals of simplicity, sincerity and unaffected naturalness - fitting material, one would imagine, for Nazi propaganda. Certainly the Nazis appealed to the same values in their battle against what they denounced as the cold and destructive intellectualism of the Jews. But the fact remains that the play was not to the liking of the Nazis, ${ }^{7}$ and this is perhaps why the parallels

${ }^{6}$ Penthesilea was produced in the Nazi-sponsored Kleist Week of 1936 along with all the other plays written by Kleist, and alongside Die Hermannsschlacht in the Kurmärkische Festspiele of 1937. Reeve (n. 5 above), 147, points out that overall, "[c]ompared to the four theatrical seasons before the Nazi assumption of power, the number of productions and performances of Kleist plays more than doubled." With 146 performances in the 1933-34 season Die Hermannsschlacht was the most often produced play in Germany. See also Hinrich C. Seeba, "Die Filzlaus im Leib Germaniens: Kleists Hermannsschlacht als Programm ethnischer Säuberung," in Kleist im Nationalsozialsmus, ed. Lothar Jordan (Würzburg: Königshausen and Neumann, 2007), 45-60.

${ }^{7}$ For exceptions in Silesia and Berlin (at Das Deutsche Theater) to the general pattern of Penthesilea and Die Hermannsschlacht productions in Germany, see Wojciech Kunicki, "Zur Rezeption Heinrich von Kleist in der NS-Periode in Schlesien" and Alexander Weigel, "Gedämpftes Saitenspiel: Heinrich von Kleist, das Deutsche Theater und sein Direktor Heinz Hilpert 1934-1944," in Jordan (ed.), Kleist im Nationalsozialismus (n. 6 above), 61-75 and 79-113. In 1943 the Nazi propaganda machine persuaded Hilpert whose Kleist cycle had so far included neither Penthesilea nor Die Hermannsschlacht to produce Penthesilea, but the propaganda weekly Der Stürmer criticised that production for its lack of pro-war enthusiasm. Subsequent plans of Goebbels' Propaganda Ministry for 
between the Amazon and Nazi ideals also tended to be overlooked by those who re-introduced Penthesilea to the German stage after $1945 .^{8}$ (Admittedly, stage directors were also little interested in looking at The Battle of Hermann for evidence that Hermann was a forerunner of Hitler.') Hans Neuenfels' brilliant 1981 Berlin production of Penthesilea was an exception in its exposure of similarities between certain features of Kleist's play, Prussian militarism, and the Third Reich. According to a magazine review by Hellmuth Karasek, Neuenfels presented Kleist's Amazons as a bizarre bevy of maidens who lived in a kind of castle of the Teutonic Order, half temple of mysteries and half boarding school for young girls; holding hands and gathering flowers, these girls reminded Karasek of the perverse chastity of the $B D M$ (the Nazi German Girls League) and "SS-Zuchtburgen" (Karasek's term for boarding schools for boys, run by the SS for the training of the future SS elite), a world of total sexual repression from which Penthesilea finally breaks free-transformed into a blood-stained murderer. ${ }^{10}$

Hilpert to produce Die Hermannsschlacht became obsolete by Goebbels' decree of 20 August 1944 that all German theatres must be closed.

8 The first production of Penthesilea after the war took place in 1954 in Hamburg. From the end of the sixties, Penthesilea was produced by well-known directors such as Karl Heinz Stroux (in Düsseldorf, 1969), Klaus Michael Grüber (1970), Wilfried Minks (1980), and Hans Neuenfels (Berlin, 1981; this production was turned into a film in 1983).

9 According to Sonja Luykens, Weser-Kurier, 13/14 Nov. 1982, Claus Peymann's production of Die Hermannsschlacht (1982, in Bochum), in which Hermann wore a beret recalling photos of Che Guevara, was in fact an attempt to ridicule Hermann's rhetoric of hatred and cruelty, and to show to what horrible ends a nationalist justification of barbarity can lead. Yet Reeve (n. 5 above), 154, also quotes a reviewer who complained that this production did not convey the demonic nature of a demagogue who seduces the people by preaching hatred and genocide. Literary criticism was much more direct than the stage, and much earlier, in denouncing the "unbearable" features of Die Hermannsschlacht which anticipate Nazi ideology; see, for instance, Siegfried Streller, Das dramatische Werk Heinrich von Kleists (Berlin: Rütten \& Loening, 1966), 183.

${ }^{10}$ Der Spiegel, 13 July 1984 (quoted in Kleist, Sämtliche Werke und Briefe, vol. 2, 745-48). Reeve (n. 5 above), 97, quotes a review from Badische Neueste Nachrichten, 3 July 1981, in which the reviewer remarks that Neuenfels' Amazons remind him of $B D M$ girls. 
It is unlikely, however, that the Nazis disapproved or were even aware of Penthesilea's alleged breaking free from the sexual repression of her culture. While they would have found the notion of a woman warrior alien to their own ideal of the German woman who tends the hearth and looks after the children, they were wellacquainted with another strong female character from German mythology: Brünhild of the middle-high German epic Song of the Nibelungs, who is physically much stronger than her husband Gunther and on their wedding night shackles him by his hands and feet with her belt and hangs him up on a nail in the wall. A feature which the Nazis are likely to have found much more objectionable in Penthesilea is her mental illness, to them a defect unacceptable in a member of the Aryan race: they would have regarded her, for all her strength, as an inferior human being. It cannot have taken them long to arrive at this conclusion, given the many instances in the play where Penthesilea is accused of madness. She herself insists, after her murder of Achilles, that she "was not quite as mad as [her fellow Amazons] would have it" (417 [line 2999]); and the very argument that she offers in support of her assertion, that she truly "ate him up for love" while many a "fool" of a girl merely pretended to do so, is proof of her ongoing madness, as she confuses consistency with sanity.

A similar confusion was of course one of Hitler's main characteristics, and his critics have often pointed to it as one of the signs of his madness-his insistence that what he saw as the hallmark of German decency, steadfast adherence to ideological principles, had to prove itself at all cost, even unto death or, as in his own case, suicide. ${ }^{11}$ Thus, the multiple parallels between Hitler and Penthesilea would seem to reach their culmination in their respective suicides. However, as I shall show in this essay, such a view would be unfair: in spite of her horrendous brutality, Penthesilea's madness deserves our pity rather than our disgust, whereas Hitler's madness, though responsible for the tragic deaths of countless human beings, disgusts us due to a complete lack of any signs of tragic suffering in the madman himself. I shall first look at Penthesilea's madness as the main driver of the play's dramatic development, and secondly interpret her madness, from a

\footnotetext{
11 Ian Kershaw, Hitler 1936-45: Nemesis (London: Penguin, 2000), 784, speaks of Hitler's "warped and peculiar brand of logic" and his "irrational and pointless principle of 'heroic' self-sacrifice."
} 
Freudian perspective, as an illness. After that I shall focus on the quasi-Nazi aspects of her actions, and conclude the essay with a comparison between Penthesilea's suicide and the suicides of Kleist and Hitler to evaluate the play's achievements as well as shortcomings, with early nineteenth-century realism rather than Goethe's Weimar classicism in mind. ${ }^{12}$

Goethe was certainly justified in remarking on Penthesilea's strangeness, but the latter needs to be seen in the context of Kleist's efforts to present Penthesilea as a fitting symbol of the defectiveness of our world. Her brutality is counterbalanced in the play with accounts, drawn mostly from the Iliad, of the brutality of Achilles; seen against Achilles' treatment of the dead body of Hector in the Trojan war, Penthesilea's brutality, unleashed in the clash between the Amazons and the Greeks, appears much less extraordinary. At the same time, both protagonists, like the two warring nations of which they are the king and queen, are characterised by their attempts to establish sustainable human relationships. Ironically, it is these attempts which result in their destruction and self-destruction: a paradox which, Kleist suggests in Penthesilea, is part and parcel of the "crumbling"13 state of the world. Each attempt to transform the world into a less destructive

12 In response to George Steiner's criticism, voiced in The Death of Tragedy (London: Faber and Faber, 1961), 227-28, that Penthesilea "cries havoc so relentlessly that it turns into an exalted piece of grand guignol," and that it "carries too far the conceit that love and death are kindred," Anthony Stephens in Heinrich von Kleist: The Dramas and Stories (Oxford/Providence: Berg, 1994), 125 , points out that, while Steiner "is not far away from Goethe's criticism of the play," "in Kleist's terms, excess is realism."

13 When Penthesilea, having returned to the Amazons after her murder of Achilles, wrongly believes that she has arrived in Elysium, Prothoe corrects her with the words: "It is the world, our transient, brittle world, / On which the gods look down but from afar" (412 [lines 2854-55]). 
one must lead us, in a circle, ${ }^{14}$ back to the same inhuman state of affairs.

This tragic view of the world informs the very structure of the play. Although Kleist, for the sake of the uninterrupted flow of the tragedy, avoided a division into acts, the 24 scenes can be easily grouped into five traditional acts, arranged to reflect the opposing world views of the Amazons and the Greeks. The first act (scenes 1-4) presents the war and the first encounters between Penthesilea and Achilles from the Greek point of view, and the second (scenes 5-11) introduces the Amazon perspective. The third act (scenes 12-15) belongs to Penthesilea who is here given the opportunity to acquaint Achilles with the Amazon point of view. (There is no equivalent attempt made by Achilles to explain the Greeks' position to Penthesilea, as she never asks for such an explanation in the mistaken belief that she is familiar with it already.) The understanding between Penthesilea and Achilles in scenes 14 and 15 appears to promise a happy end, but then the fourth act (scenes 16-21) presents us with the peripeteia of the tragedy, the fatal reversal of fortune, and the point of view now shifts rapidly back and forth as the drama approaches its tragic conclusion. It is here that Achilles is given a crucial part to play in the development of the plot. In the long term, in violation of the Amazon laws and Penthesilea's own wishes, he intends to make her the mother of his son and to take her with him to Phthia, his kingdom in Greece. However, in order to make things easier for her in the short term at least, he devises a plan whereby he will let her defeat him in a mock combat and so allow her to save face before her people. While this scheme is perfectly in tune with Achilles' rationally political, "Greek" mind, it is altogether foreign to Penthesilea, whose Amazon way of thinking is not geared towards doubledealing of any kind. When he challenges her to the combat, she therefore takes his words at face value and believes that he is out to

14 See also Elisabeth Krimmer, "The Gender of Terror: War as (Im)Moral Institution in Kleist's Hermannsschlacht and Penthesilea," The German Quarterly 81, Issue 1 (Winter 2008): 79: "Kleist's plays [sc. Hermannsschlacht and Penthesilea] conceive of history as a vicious circle: wars engender female and male monsters intent on waging war. Both [...] portray war as a vortex, an ungovernable dynamic apt to eradicate every feature of civil society. Civil society, on the other hand, is itself the continuation of war by other means." 
defeat and humiliate her yet again. Overcome by an insane desire for revenge, she goes off to attack him with bloodhounds and elephants, knowing full well that he is prepared for no more than single combat. The fifth act brings the catastrophe: having awoken from her attack of madness, Penthesilea discovers what she has done to Achilles, and commits suicide to atone for her crime.

When she first re-appears with Achilles' dead body, however, she is still in a trance-like state, and the Amazons observe her in horror as she quietly cleans the arrow with which she had killed Achilles and replaces it in her quiver. Then, with a violent shudder, she suddenly drops her bow, the symbol of her royal authority which she had inherited from her mother and, through her, from Tanais, the founding queen of the Amazons. This cannot fail to remind us of an earlier episode which Penthesilea herself had narrated to Achilles in scene 15. The bow, as she tells him, was originally intended to be handed to Tanais by the then high priestess in a ceremony which would give religious legitimacy to her power, so that she could then receive the Crown from the assembly of the people. Yet the ceremony was rudely interrupted by a voice from the crowd, warning that a state of women, hindered by their breasts in using a bow effectively, would merely invite the mockery of men and end in failure. To quell the voice of opposition, Tanais tore off her right breast and fell fainting to the ground. Her drastic action not only gave the Amazons their name (the "Breastless"), but also silenced the remaining doubts of her people, so that she was crowned without any further delay. However, the high priestess was so abhorred by her brutal act of self-mutilation that "the bow / Fell whirring from the bloodless, lifeless hand / Of the high priestess to the temple floor" (380 [lines 1995-97]). ${ }^{15}$ When Penthesilea lets the bow plunge to the earth, the three stages of the fall are described in similar terms by the Amazons looking on, who then state that the bow "dies at last, / As it was born at first to Tanais" (408 [lines 2771-72]). There is a clear parallel between Penthesilea and the former high priestess in

15 Michel Chaouli, "Devouring Metaphor: Disgust and Taste in Kleist's Penthesilea," The German Quarterly 69, issue 2 (1996): 135, interprets this scene differently by referring to "the fall-Sturz — of the bow which the high priestess had held out for Tanais to mark her ascent to the throne but which now, with the queen's collapse, has nowhere to go but down." If this were correct, the crown would have fallen as well. 
their sudden inability to accept the principle of mutilation on which the Amazon state had been founded and "baptised" by Tanais (380 [line 1986]): Kleist uses the motif of the falling bow to reinforce his message of the inescapable tragedy of any attempt to change the world for the better, his message of the vicious circle. Although Penthesilea atones for her murder of Achilles not only by committing suicide, but also by renouncing the laws of the Amazons, neither of these responses will make any difference to the state of "our transient, brittle world": ${ }^{16}$ they merely refer the Amazons back to that earlier stage of their history which had led them to establish the laws in the first place, in defence against the oppressive Aethiopian men. However, her double atonement does allow Penthesilea to end her life in great tragic style, to all appearances not only at peace with herself, but also in full charge of her mental faculties.

In spite of Kleist's efforts to make his heroine represent his tragic view of the world, stage directors as well as scholarly critics have tended to focus more narrowly on Penthesilea's brutality, in recent years highlighting her cannibalism as the most striking of her characteristics. ${ }^{7}$ This approach has its obvious justification in the pivotal importance of her murder of Achilles, but so far it has not been accompanied by a convincing analysis of the nature of the madness which causes her to regress to such outrageous barbarity. Penthesilea's extreme violence cannot be seen as a natural response to her wounded pride, even in the context of the warlike customs of the Amazons: after all, her people themselves express their repugnance at her brutality. Throughout the play they also ponder, without success, what might be the motive for their queen's strange pursuit of Achilles. However, Kleist does provide a number of clues for her behaviour: not only the murder of Achilles, but also her suicide in the final scene. With the help of these clues it is possible to detect the tragic centre of her character

\footnotetext{
${ }^{16}$ See n. 13 above.

17 As early as 1982, Christa Wolf, "Kleists Penthesilea," in Die Dimension des Autors: Essays und Aufsätze, Reden und Gespräche 1959-1985, by Christa Wolf (Darmstadt und Neuwied: Luchterhand, 1986), 675, suggests that the shock which we experience from Penthesilea is caused by the fact that Kleist made a strict taboo, the cannibalism of our culture, a topic of art. (When she insists that we are not justified in accusing Penthesilea of barbarousness [674], Wolf is clearly not using the German word "Barbarei" in its second sense, "barbarity.")
} 
that makes her stand out from her fellow Amazons and also separates her from Achilles. (While the Greeks around Achilles are similarly puzzled by the intensity of his interest in Penthesilea, the play gives no clues regarding that question.)

The presence of a self-destructive urge in Penthesilea is already suspected by the high priestess in scene 7: on hearing that the queen has fallen in love with Achilles and is recklessly prolonging the battle on his account, she darkly comments that it is not Achilles who will make Penthesilea run "steeply down to the Abyss," but her own "inner foe" (349 [lines 1106-08]). ${ }^{18}$ We are given a first hint of the nature of this inner foe in scene 9, by the strangely morbid terms in which Penthesilea expresses her disappointment at having failed to defeat Achilles: "Would God the spring / Should winter and die! / Would God this plane Earth / lay plucked and broken like these roses here! [...] / Oh, I am weary! Deadly, deadly tired!" (353 [lines 1226-28 and 1237]). The suspicion raised here that her words are the expression of an unconscious death wish is strengthened later in the scene, when, in an attack of madness, she almost kills herself by drowning. Staring at the sun, she confuses it, in the guise of the sun god Helios, ${ }^{19}$ with Achilles, and wishes that she had wings to join him in the sky; but then she confuses her own reflection in the water with Helios/ Achilles, and she has to be prevented by the other Amazons from throwing herself into the stream to join it, crying "Why, there he is below me! Take me! I come-" (359 [line 1388]).

18 Joël Lefebvre, "Nécessité et limites d'une lecture psychoanalytique de Penthésilée," Cahiers d'Etudes Germaniques 10 (1986): 233, takes these words of the high priestess as the starting point for his outline of a psychoanalytical interpretation, according to which Penthesilea, seen as a precursor of Freud's scientific analyses, is a clinical study on Eros and Thanatos, a play about a neurosis which results in the murder by the protagonist of her lover and, once she has become aware of the ravages caused by her unconscious drives, in the suicide of the murderess. At the end of his article, Lefebvre suggests that a psychoanalytical interpretation which is only based on the inner motivation of the protagonist needs to be extended by an ethnological investigation, and that such an investigation would also prove Kleist to have been a precursor of Freud (241).

19 On Achilles as Helios and Mars see Justus Fetscher, "Ach, dieser Kranz von Wunden um sein Haupt!': Zur erotisierten Christus-Imago der Penthesilea," in Beiträge zur Kleist-Forschung 2003, ed. Lothar Jordan (Kleist-Museum: Frankfurt [Oder], 2004), 97. 
It soon becomes evident that her desire to die is more than a response to her defeat by Achilles. In scene 14, when Prothoe wrongly tells her that Achilles has been vanquished, she is wild with joy, yet expresses her happiness in the following terms: "Not harsh, my Prothoe! Let my poor heart / Like a dirt-dappled, happy child, sink deep / One wondrous moment in the stream of joy / [...] I Ne'er was I half so ripe for death as now" (370, lines 1674-76 and 1682; italics mine). Regardless of whether the circumstances seem to her to favour or to damage her prospects of overcoming Achilles, her underlying thoughts always seem to tend toward death.

It is conceivable, of course, that what Penthesilea sees in the water and confuses with Achilles in scene 9 is not her own reflection, but that of the sun which she had earlier seen in the sky. Yet later on, in scene 15, she clearly connects the image of the sun with herself, when she encourages Achilles to "look on me now as thy sun" (373 [line 1755]). So however we interpret her words, her unconsciously suicidal wish to cast herself into the water is likely to recall the myth of Narcissus who, falling in love with his own image in the water and trying to unite with it, not only destroys the image in the water, but drowns in the process. ${ }^{20}$ There are clear differences, of course. Narcissus' death is an accident, his desire to unite with his image simply makes him forget the dangers of the water; Penthesilea, though just as oblivious to its peril, dies neither by drowning nor by accident but, much later, by deliberate suicide. Yet she, too, is unaware that it is she herself, rather than her lover, with whom she really wants to unite, in the sense that her attempts

${ }^{20}$ Chaouli (n. 15 above): 137, believes that what Penthesilea sees is "the sun's, and presumably her own, reflection in the water," and he speaks of Penthesilea's "insane narcissistic fantasy." Ulrich J. Beil, "Der rasende Gott: Kleist's Penthesilea und die Rolle des Anderen in der Mythosrezeption um 1800," Internationaler Germanisten-Kongreß in Tokyo, Sektion 15 (München: Iudicium, 1991), 299, mentions the possibility of interpreting the play in terms of its excessive narcissism, and Stephens (n. 12 above), 122, states that narcissism is "not merely a theme in this tragedy, but defines the relation of the figure of Penthesilea to the whole text." While neither Chaouli nor Beil expand on the term "narcissism," Stephens, ibid., 124, points to the "futility of Narcissus' desire for his own reflection," and states that Penthesilea's cannibalism "may be read as an attempt to assimilate the imagined object of desire directly into the body when all other communication has failed." However, none of these scholars mentions Narcissus' drowning. 
to unite with Achilles are in fact driven by a desire to reconcile her own, unconscious death wish with the self-image that has been imposed on her by her mother's wish that she should go to war and have children of her own. Even though she is unconscious of her death wish, its conflict with the wishes of her mother is causing her feelings of guilt, as can be seen from the fact that she not only wants to join her reflection like Narcissus, but is also interested in the purifying qualities of the water itself. In scene 14, she expresses her ill-founded joy at supposedly having defeated Achilles in these terms: "With every splash in those exultant waves / A stain is washed from my sad, sinful breast. / They flee at last, the dread Eumenides; / I feel the approach of godlike presences / And I would join my voice to their happy choir. / Never was I half so ripe for death as now" (370 [lines 1677-82]). She shows the same interest in water in the last scene of the play, when she has killed Achilles, but is not yet conscious that she has done so. Having cleansed the arrows from blood and let the bow drop out of her hands, she begins to weep, a "[h] eartrending sight, wounding more keen than knives" (409 [line 2781]). Prothoe then asks her whether she wishes to clean her face and hands, and she looks down at herself and nods, but proceeds not merely to sprinkle her head as the high priestess suggests she do in order to help her "remember" (410 [line 2812]), but to drench herself, dipping her head "right under water" (411 [line 2831]. Having done so three times, she then unexpectedly states that she feels "[b]lissfully well," and asks whether she is in Elysium (lines 2842 and 2844). Clearly it is the cleansing qualities of the water that make her consider it "good" even to be told that she is in fact still alive (412 [line 2856]). And yet, at the end of the play, it is her "remorse" (418 [line 3030]) at the murder of her lover which allows her for the first time to make the conscious decision to commit suicide, and in her final monologue she replaces her earlier, passive notion of the cleansing power of water with that of an imaginary dagger with which she can deliberately commit suicide as an act of atonement. Whereas she survives both her unconscious suicide attempts in scene 9 and in her last combat with Achilles, once her unconscious death wish has become a conscious intention to kill herself, her determination cannot be stopped, even when all 
physical weapons have been taken from her: she does not die, as one critic put it, "by the sheer force of her grief," 21 but by the sheer force of her will power, focused on the one overriding objective of ending her grief by ending her life. By this stage all her other objectives have become means to that end.

Yet while Penthesilea's relationship with Achilles is the catalyst that makes her illness reach its last, fatal stage, Kleist has made sure that the audience cannot take it as the cause of her illness. From her narration of her past in scene 15, one can gather that her problems developed before she ever met Achilles or the Amazons engaged in their war with the Greeks. As her mother Otrere lay dying, she prophesied that Penthesilea would vanquish the greatest of heroes, Achilles - this in breach of the custom that an Amazon should not have her eye on any particular man in battle, but fight whomsoever the fortunes of war cast in her way. Underlying the prophecy, Penthesilea explains to Achilles, was her mother's longstanding desire for her daughter to go into battle and have a daughter herself, so as to secure an heiress to the Amazon throne. Penthesilea's fury when he announces at the end of the scene that she shall bear him "the god of Earth" (387 [line 2230]), rather than a daughter, is thus understandable. However, her anger can only partly be attributed to the fact that he wants a son. It is the prospect of motherhood as such which seems to upset her: we only ever hear of her mother's desire for her to have a daughter, never that she herself wants Achilles to become the father of her child. It is also revealing that for a full month after Otrere's death she continued to ignore Ares' call to war, in spite of her mother's wishes. When she was no longer able to withstand the clamour of her people for her to leave Otrere's grave and accept the responsibilities of the throne, she learned to love "the universe of joyful war" (386 [line 2177]) by persuading herself that in the whole history of the Greeks there was no worthier object of her love than Achilles. Yet even now she points out that it was for the sake of "that dear shade-my mother's, great Otrere's," that she went into battle, and refers to Achilles as "that man whom my mother chose for me" [line 2184].

The features which Penthesilea imagined Achilles to have when she went into battle- "So dear, so wild, so sweet, so terrible-/ The

${ }^{21}$ Robert E. Helbling, The Major Works of Heinrich von Kleist (New York: New Directions, 1975), 162. 
slayer of Hector!" [lines 2185-86]—are not only contradictory and ambivalent, they also lead us to wonder whether there is not a streak of sadism ${ }^{22}$ in Penthesilea. This streak in fact emerges as early as scene 9, from her outrage at having been wounded by Achilles. Her anger is completely out of proportion to her injury: in a feeble voice, but furiously determined, she orders her fellow Amazons to "[s]et all the dogs upon him! Whip the elephants / With blazing faggots that they trample and crush him! / Drive over him with our steel-scythèd cars! / Mow down his sumptuous limbs and mangle them!" (351 [lines 1170-73]). This closely anticipates, of course, what she herself will do to him at the end of the play. Yet later in the scene she also wants Achilles to do to her what he had done to Hector: ${ }^{23}$ far from pursuing her intention to attack him, she cannot even muster the strength to flee, declaring that because of her inability to attract Achilles she deserves to be left behind by the fleeing Amazons to be defiled and killed by him, as punishment for her aspirations to his love: "Why are these cheeks / In youthful loveliness still loath to mingle / With mud, the primal matter, from which they sprang [...] Much better dust than thus a woman scorned!" (354 [lines 1245-53]). Not only are her words regressive and suicidal, but, just as she had earlier foreshadowed her gruesome attack on Achilles at the end of the play, they anticipate her suicide after the murder, and her justification of it.

They also bring to mind Sigmund Freud's classic paper "Mourning and Melancholia," which deals with, among other things, the extreme mood swings which are experienced by those who suffer from the pathological state that he terms melancholia-what in

22 According to Steiner (n. 12 above), 228, Penthesilea "reflects the strain of hysteria and sadism which runs just beneath the surface of romanticism, from the age of the Gothic novel to that of Flaubert and Oscar Wilde's Salomé."

${ }^{23}$ With reference to Penthesilea's view of Achilles as the slayer of Hector, Stephens (n. 12 above), 112, states that she "can scarcely escape an awareness that she is reaching toward something of which her own destruction is part. [...] The expression of Penthesilea's death wish is thus one of the most finely crafted aspects of Kleist's drama, since it is subtly and inextricably interwoven with her desire for love and life." 
today's clinical terminology of affective disorders would be called "adjustment disorders," "dysthymic disorders" or "bipolar disorders." 24 In mourning, according to Freud, "it is the world which has become poor and empty, in melancholia it is the ego itself": the melancholic "reproaches himself, vilifies himself and expects to be cast out and punished. He abases himself before everyone (...). ${ }^{, 25}$ Freud considers such self-denigration to be the result of a failed separation of the ego from the lost object; instead of exchanging the lost love object for a new one, the ego retreats into itself, in what Freud calls the narcissistic identification with the lost object. Any ambivalence of the original relationship, exacerbated by the melancholic's mental revolt against the reality of the loved object having left the ego, is therefore also displaced onto the ego, and the melancholic turns his/her aggression against himself/herself. ${ }^{26}$ Mourning itself, the starting point of Freud's argument, is a natural process: for all the mourner's difficulties in coming to terms with the loss of the loved one and the "great expense of time and cathartic energy" which the process demands, in the end "respect for reality gains the day" (245). Melancholia, on the other hand, involves a loss which has been withdrawn from consciousness: even though melancholics may know whom they

${ }^{24}$ Cf. David A. Tomb, Psychiatry (Philadelphia, Baltimore, New York, London: Lippincott Williams \& Wilkins, 1999), 6th edition, 40-49.

25 Sigmund Freud, "Mourning and Melancholia," in Standard Edition of the Complete Psychological Works, by Sigmund Freud, trans. from the German under the general editorship of James Strachey, in collaboration with Anna Freud, vol. XIV (London: The Hogarth Press, 1957), 246. "Mourning and Melancholia" was first drafted in 1915 and published in 1917.

${ }^{26}$ In the words of Sigmund Freud, ibid., 249: "The object-cathexis proved to have little power of resistance and was brought to an end. But the free libido was not displaced on to another object; it was withdrawn into the ego. There, however, it was not employed in any unspecified way, but served to establish an identification of the ego with the abandoned object. Thus the shadow of the object fell upon the ego, and the latter could henceforth be judged by a special agency, as though it were an object, the forsaken object. In this way an object-loss was transformed into an ego-loss and the conflict between the ego and the loved person into a cleavage between the critical activity of the ego and the ego as altered by identification." 
have lost, they do not know what they have lost in a wider sense, and so cannot consciously come to terms with their loss. This is the case with Penthesilea who, after the death of Otrere, can be said to have mourned not only the loss of her mother, but also, unconsciously, the impending loss of her childhood. However, Penthesilea's case is more complicated than one would have anticipated from Freud's paper: when she could no longer avoid leaving the grave of her mother to go off to war and have a childbecome an adult, ${ }^{27}$ in other words-there was no immediate transferral of her resentment of her mother onto herself. Yet her attempt to comply with the wishes of Otrere left her unconscious resentment unaddressed, simply shifting her ambivalent feelings towards her mother onto Achilles. As this new love-hate relationship can be seen as a substitute for her mourning in her attempt to cope with the loss of her mother, it seems safe to say that Freud's findings on the symptoms of melancholia still apply.

Freud explicitly mentions sadism as a possible characteristic of the ambivalent relationship of narcissistic identification: "If the love for the object - a love which cannot be given up though the object itself is given up-takes refuge in narcissistic identification,

27 Peter Staengle, "Im Geklüfft': Notizen zur Penthesilea," Brandenburger Kleist-Blätter 5 (1992): 24, stresses that the characters in Kleist's plays cannot be understood in psychological terms, and he lists an impressive number of scholars who have made similar statements. Yet he himself uses the psychological term "regression" to explain why Achilles and Penthesilea use force against each other (22). He does not bother to specify this term, however, evidently because he believes that in a world which is characterised by splits ("Spaltungen") even the apparently unsplit will prove to be split anyway (21). ("Was vermeintlich jenseits der Spaltungen liegt, kann unter den Bedingungen der Spaltung nur selbst als Gespaltenes erscheinen.") Wolf Kittler, Die Geburt des Partisanen aus dem Geist der Poesie: Heinrich von Kleist und die Strategie der Befreiungskriege (Freiburg: Rombach, 1987), 187, explains Penthesilea's insanity by her nature as a female ("weibliche Natur"), which will not be suppressed by artificial laws: Penthesilea would rather eat up her lover than do without the longed-for union with Achilles. This interpretation makes Penthesilea (and women in general) appear nymphomaniacal, although there is no hint at this in the play at all, apart from, supposedly, the scene of the murder of Achilles. In spite of this lack of evidence, Chaouli (n. 15 above): 138, talks about "the very driving force of the playPenthesilea's nymphomaniacal desire." 
then the hate comes into operation on this substitutive object, abusing it, debasing it, making it suffer and deriving sadistic satisfaction from its suffering" $(251) .{ }^{28}$ According to Freud, it is "this sadism alone that solves the riddle of the tendency to suicide which makes melancholia so interesting-and so dangerous" (252). ${ }^{29}$ It is therefore consistent with Freud's description of the ambivalent attitude of melancholics to their love object that Penthesilea in scene 15 should be fascinated by the image of a cruel Achilles, who threw Hector to the ground even as he fled and, "enflamed in lust of victory," turned "back to look upon his head, / Bloody and battered by the ungentle ground" (386 [lines 219698]): unconsciously she yearns to do to Achilles what he had done to Hector, and to receive the same treatment from Achilles. This ambivalence of her feelings for Achilles originates in her unconscious expectation that he will make it possible for her to die rather than give birth to a child which would destroy her own status

${ }^{28}$ The substitute object which Freud has in mind in this quotation is the ego itself. Since Penthesilea has shifted her ambivalent feeling towards her mother onto Achilles, her sadism at that stage is deflected toward him; it can only be fully directed against herself after she has killed him.

${ }^{29}$ While Elisabeth Bronfen, "Liebeszerstückelung: Penthesilea mit Shakespeare gelesen," Kleist-Jahrbuch (1999): 185, discusses Penthesilea in Freudian terms and talks about Penthesilea's "Trauerarbeit," a term used in "Mourning and Melancholia" for "the work which mourning performs" (Freud [n. 25 above], 244), she misses not only Freud's distinction between normal mourning and melancholia as a serious illness, but also his point about the connection between the latter and a tendency to suicide. Bronfen suggests that Penthesilea's case can be read as anticipating Freud's "Wiederholungstrieb" (183), that is "repetitioncompulsion": as Penthesilea needs to become like her mother (186), and in fact like all the other Amazon mothers, she pursues to its logical consequence a love which has always been obsessed with death, as it is oriented towards a genealogy of dead mothers ("eine immer schon vom Tode besessene, weil auf eine Genealogie von toten Müttern gerichtete Liebe bis zur logischen Konsequenz durchspielt") (178). The point is well made, but fails to explain the particular nature of Penthesilea's case, and it overlooks Kleist's message of the circle which starts with the foundation of the Amazon state and finishes with Penthesilea's renouncing of the Amazon laws. Furthermore, Penthesilea's death does not mimic that of her mother or of any other Amazon queen, including the first queen Tanais, as not one of them is reported to have suffered from severe mourning at the death of their mother or from a tendency to suicide; rather, Penthesilea becomes like the former high priestess in her disenchantment with Tanais, the founding mother of the Amazon state. 
as a child. On the conscious level, however, her wish is for a gentle and compassionate lover, and she tries in vain to make sense of her ambiguous feelings towards Achilles by imagining that as her lover he will combine the quality of pitilessness with that of a kind and sweet man: "And I wept scalding tears of joy to think / That some emotion yet, thou pitiless man, / Could penetrate and stir thy flinty bosom" (386 [lines 2200-02]).

Even before exploring the connection of melancholia with sadism and masochism, and with the melancholic's suicidal tendency, Freud addresses the fact that melancholia has the tendency to change round into mania, where the individual exhibits symptoms of exultation or triumph that make it appear the opposite of melancholia. It is a particularly dangerous state, because it leaves the melancholic "in such high spirits on the one hand and so uninhibited on the other" (254). In the light of Freud's interpretation of melancholia, we may therefore regard not only the killing of Achilles, but also Penthesilea's suicide as occurring during a fit of mania, and while Penthesilea's murder of Achilles seems far more obviously an instance of mania than her consciously chosen suicide, we must remember Freud's observation that, "What consciousness is aware of in the work of melancholia is [...] not the essential part of it, nor is it even the part which we may credit with an influence in bringing the ailment to an end" (257). Prothoe's final comment, that Penthesilea died from too much rather than too little health, thus shows her to have fallen into the same trap as all those observers of mania in real life who, as Freud points out, are mistaken if they believe "that a person in a manic state of this kind finds such delight in movement and action because he is so "cheerful'" (254).

Freud's statement helps us to evaluate the relief expressed by Penthesilea's last words at the solution finally achieved by her suicide (418, "Now it is good"), as well as the particular circumstances of Kleist's own suicide four years after writing Penthesilea. This was a suicide pact with his lover Henriette Vogel, who suffered from a terminal illness and, on his prompting, had agreed that he should kill her. In this respect, that he also felt 
the need to kill his beloved before killing himself, Kleist's suicide seems to follow the pattern of Penthesilea's death. However, ultimately his death looks merely like a rather sad parody of his heroine's: unlike Penthesilea, who is tragically unaware of what she is doing when she kills Achilles in the prime of his health, Kleist killed his lover Henriette Vogel deliberately, knowing that she would soon die in any case. Nevertheless, his cheerfulness at his own imminent death ${ }^{30}$ suggests that his suicidal drive was the result, like Penthesilea's, of a serious illness, ${ }^{31}$ and this is corroborated by the fact that he had already planned several other suicide attempts which were aborted each time because of the lack of others who could be persuaded to join him. ${ }^{32}$

This brings us back to our initial question of the comparability of Penthesilea's and Kleist's extremism with that of Hitler. Unlike Penthesilea, who kills herself in order to work off her own feelings of guilt, Hitler apportioned all guilt of the lost war to others- the Jews, the Bolsheviks, the German officers and those party leaders who, like Goering and Himmler, had betrayed their Führer by trying to negotiate Germany's capitulation with the enemy. ${ }^{33}$

${ }^{30}$ Letter to Marie von Kleist, 21 November 1811: "Ach, ich versichre Dich ich bin ganz seelig. Morgens und Abens knie ich nieder, was ich nie gekont habe, und bete $\mathrm{zu}$ Gott; ich kan ihn mein Leben das allerqualvollste daß je ein Mensch geführt hat jezo dancken, weil er es mir durch den <herrlichsten> und wollüstigsten aller Tode vergütigt" (Briefe von und an Heinrich von Kleist, ed. Klaus Müller-Salget and Stefan Ormanns [Frankfurt am Main: Deutscher Klassiker Verlag, 1947], 510).

31 Wolf (n. 17 above), 673-74, sees the parallel between the tragedy of Penthesilea and Kleist's own life when she states that he knew Penthesilea's soarings and breakdowns, her longing to die and her determination to die, from his own experience.

${ }^{32}$ Kleist reminds Marie von Kleist of this fact in the same letter of 21 November 1811, where he praises Henriette Vogel with the following words: "Der Entschluß der in ihrer Seele aufging mit mir zu sterben, zog mich, ich kan dir nicht sagen mit welcher unaussprechlichen und unwiederstehlichen Gewalt an ihre Brust, erinerst Du Dich wohl daß ich Dich mehrmals gefragt habe, ob Du mit mir sterben wilst? - Aber Du sagtest immer nein — Ein Strudel von nie empfundner Seeligkeit hat mich ergriffen, und ich kan Dir nicht leugnen, daß mir ihr Grab lieber ist als die Betten aller Kaiserinnen der Welt."

${ }^{33}$ William S. Shirer, The Rise and Fall of the Third Reich: A History of Nazi Germany (London: Secker and Warburg), 1960, 1115-16. Fritz Redlich, Hitler: 
Moreover, the German dictator does not seem to have been plagued by either conscious or unconscious suicidal thoughts ${ }^{34}$ until he actually committed suicide together with Eva Braunindeed, he postponed his own death for as long as possible - nor to have had any reason to regard his death as an atonement for her death, as she joined him in his death of her own free will. However, he, too, used his companions in suicide - of whom Eva Braun was only one - to present his death in a positive light. This is evident from the two testaments which he dictated on the day before his suicide. Read together, they remind us that in his fight on behalf of the German people he regarded himself bonded to Germany in a way which prevented him from entering a conventional marriage. In the first testament, the so-called "Political Testament," in which he complains about those who have not been willing to fight for their Führer unto death, there is little more than an indirect hint of this in his claim that, "In these three decades, love and loyalty to my people alone have guided me in all my thoughts, actions and life." ${ }^{55}$ Yet in his second, private testament, he makes it quite clear that it is only now, one day before his death, that thanks to Eva Braun's loyalty he is able to marry her: "She will go to her death with me at her own wish as my wife. This will compensate us both for what we lost through my work in the service of my people. ${ }^{.36}$ In marrying her, he not

Diagnosis of a Destructive Prophet (Oxford, New York, etc.: Oxford University Press, 1998), 306, sees Hitler as "a paranoid fanatic," whose fanaticism is fed by "a delusion that the Jew harmed him and the world."

${ }^{34}$ Cf. Redlich (n. 33 above), 280: "Self-destruction inevitably implies selfpunishment, and I do not feel sanguine about the notion that Hitler had guilt feelings over his terrible deeds and preconsciously tried to punish himself. Hence, the assumption of self-destructiveness, in spite of Hitler's suicide, is tenuous." According to Redlich, Hitler suffered grief reactions after the deaths of his father and mother, with whom he had ambiguous relationships, and after the suicide of his niece Geli Raubal with whom he appears to have had an intimate relationship, but "[a]t no time can a severe enduring or psychotic depression be detected." Even after Geli's death, "Hitler bounced back quickly, returning to a very active political life within a week [...]" (292).

${ }^{35}$ Shirer (n. 33 above), 1124.

${ }^{36}$ Ibid., 1127. 
only gave in to Eva's personal whim, ${ }^{37}$ but continued to think in terms of his political advantage. We may be sure that in his eyes Eva Braun represented the true Germany, characterised by the "Nibelungentreue" of the old Germanic epic, safeguard of the future of National Socialism: in freely deciding at the last moment to die with and for him in the bunker, she sustained his belief that his vision of Germany had not been a mere illusion, but would survive his death. Again, from his "Political Testament": "I die with a joyful heart in my knowledge of the immeasurable deeds and achievements of our peasants and workers and of a contribution unique in history of our youth which bears my name." Although National Socialism was finished for the moment, he predicted that from the sacrifices of this war "the seed has been sown that will grow one day ... to the glorious rebirth of the National Socialist movement of a truly united nation." 39

Hitler's exploitation of Eva Braun's death was an extension of his disregard for the lives of his people as a whole, and of human beings in general. A similar attitude can be detected in Penthesilea's lack of concern for the lives of the Amazons when she insists that they resume the already finished war against the Greeks so that she can vanquish Achilles. And later, when she is confronted with Achilles' dead body, it is only his horrible mutilation which upsets her, not the death as such; she is not interested in discovering the murderer, giving as her reason that this is simply the way her "whimsy jumps" (415 [line 2924]): a response worthy of the worst tyrant, not of a responsible commander, or a lover. In the end, with the admonition that the Amazons should give up their Amazon laws, that is turn to true womanhood, she leaves her people to their fate, reminding us of Hitler who left the Germans to their fate, exhorting them in his will to follow the path of true Germanness. Her request, that the Amazons scatter Tanais' ashes to the winds, appears self-righteous in her certainty that she is thereby righting the wrongs committed by the founder of the Amazons. This is the same self-righteousness which is exuded by Hitler's last will. In addition, her suicide by

${ }^{37}$ Cf. Kershaw (n. 11 above), 821: "The marriage now cost him nothing. He did it simply to please Eva Braun, to give her what she had wanted more than anything at the moment when marrying him was the least enviable fate in the world."

38 Shirer (n. 33 above), 1125.

39 Ibid. 
force of sheer willpower, which Kleist intended would show her at the peak of her strength, recalls the particular pride that Hitler took in his willpower which in his rhetoric he characterised as iron, relentless, fanatical, and which, in his view, his suicide confirmed one last time rather than compromised: ${ }^{40}$ his decision to defend Berlin to the end, to die a hero's death by taking his own life, was a last demonstration of this willpower, against the wishes of his advisors who wanted him to escape to Bavaria. Another parallel can be seen in the way in which Hitler and Penthesilea carry out their respective suicides. Those who went into Hitler's room afterwards detected that, although two revolvers had fallen to the floor, Hitler alone had shot himself in the mouth; Eva Braun had taken poison. Clearly the two revolvers were meant to enable them to kill themselves at the same time, and the poison was there as a backstop. ${ }^{41}$ Penthesilea, too, is not content to forge an imaginative dagger for her suicide, but steeps it in the "venom of remorse" (418 [line 3029]): an over-precaution matching the extreme brutality of her murder of Achilles. The final parallel involves both selfdeception and deception: Hitler firmly believed that by his suicide he would achieve a hero's death, inspiring the Germans to finish the historical task which he had to leave unfinished; Penthesilea's ability to commit suicide depends on her belief that in so doing she will finally be united with Achilles, in accordance with the wishes of her mother. In his last will, Hitler ordered that his dead body be burnt so that his memory would not be tarnished by his death, and his successors told the Germans on the radio that he had fallen in battle, fighting the Bolsheviks. Of course, Penthesilea does not

\footnotetext{
${ }^{40}$ In 1943 Hitler had voiced bitter disappointment when General Field Marshal Paulus, Commander of the $6^{\text {th }}$ Army in Stalingrad, surrendered himself and his troops to the Russians in Stalingrad: "How can one be so cowardly? I don't understand it [...] So many people have to die, and then a man like that besmirches the heroism of so many others at the last minute. He could have freed himself from all sorrow and ascended into eternity and national immortality, but he prefers to go to Moscow!" (Shirer [n. 33 above], 933).

41 Shirer, ibid., 1120, mentions a similar backstop considered by the test pilot, Hanna Reitsch, after Hitler, in recognition of the fact that she was willing to die in the Bunker, had personally provided her with poison for her suicide. She and her partner, General von Greim, decided that "should the end really come' they would swallow the poison and then, to make sure, pull a pin from a heavy grenade and hold it tightly to their bodies."
} 
need to take these precautions, as her imaginary weapons leave the beauty of her body intact, but the fact that she does not complain about Achilles' death, but only about his mutilation, shows that she cannot face the physical marks of death. And Prothoe's statement at the end of the play, that the queen died from too much rather than too little health, ${ }^{42}$ while not a deliberate lie, is a eulogy, spoken by a friend who wishes to shield the tragic heroine from a suspicion which must suggest itself to any impartial observer of Penthesilea's words and actions. Prothoe's comment calls to mind a statement made by Hitler to Albert Speer on 18 March 1945, that there was no need to secure even the most basic means of living for those Germans who were going to survive the war: as the German people had proved the weaker in the struggle, only those who were inferior would remain. ${ }^{43}$ In a curious twist of Darwinism, these words imply that at the end of the war the only Germans who would have deserved to have a future were going to be dead anyway, because they were stronger (like Prothoe he could also have used the word "healthier") than those who survived the war.

Yet for all the similarities between the destructive and selfdestructive force of Hitler and the brutality of Penthesilea, Hitler's death lacks tragedy, whereas we are moved by the death of Penthesilea. This is not because his madness proved far more lethal to his fellow human beings than Penthesilea's mental illness to the Amazons and the Greeks, nor because it was based on a fanatical ideology which culminated in genocide: it is Penthesilea's genuine illness and suffering which alone ensures her tragedy.

Hitler's death was the result of his megalomania, ${ }^{44}$ a highly dangerous character defect, but not a mental illness as such. It is

\footnotetext{
42 Prothoe expresses the opposition of strength and weakness in the famous metaphor: "Vainly the gale will shake the withered oak, / But with a crash he flings the living down, / Grasping with ruffian hands her copious locks" (419 [lines 3041-3043]). (The word "living," used in the English translation for the German word "gesund" [healthy] is somewhat misleading.)

43 Summarised in Kershaw (n. 11 above), 785.

44 According to Kershaw, ibid., xvi, as early as 1936 Hitler's "narcissistic selfglorification had swollen immeasurably under the impact of the near-deification
} 
shared to some extent by Penthesilea, ${ }^{45}$ and Kleist was himself not immune from it. Yet while he did not recognise the full extent of the problem, unlike Hitler he was painfully aware of the potential for destruction and self-destruction in what he saw as the main feature of his own character, ambition. Ambition is a major concern of his last plays, The Battle of Hermann and Prince Frederick of Homburg, which now need to be included in the discussion, as this will help us to position Penthesilea not only in Kleist's oeuvre, but also in the history of German literary tragedy, and in the history of German political extremism.

In The Battle of Hermann, the hero's atrocities against both the Germanic tribes and the Romans are still justified by the playwright with the overriding nationalist objective of freedom from the atrocities committed by the Roman Empire: Hermann, just as little troubled as Hitler by suicidal thoughts, is determined to beat the Romans at their own game. In Prince Frederick of Homburg, by contrast, the hero's ambition is crushed twice by the Elector, his commander-in-chief. First he urges the prince to accept the death penalty for having attacked the Swedes against the explicit order that he should not attack until told to do so, even though his disobedience resulted in a decisive victory against the Swedes. Devastated at first, the prince gradually comes to perceive his compliance as his opportunity to achieve immortal national fame. His unexpectedly sudden and deep yearning for life in the next world suggests that in him, as in Penthesilea, the conscious decision to die had been preceded all along by an unconscious

projected upon him by his followers. By this time, he thought himself infallible; his self-image had reached the stage of outright hubris."

45 Prothoe refers to Penthesilea's megalomania in general terms in her final eulogy at the end of the play: "Her blooming was too proud and glorious!" Earlier, in scene 9, Penthesilea expresses the sudden wish, not to do anything extraordinary, but "Just to pile Ida on to Ossa, then / Quietly take my place upon the top" (358 [lines 1375-76]). When Meroe timidly protests that "This is a task for giants, Queen, not men" [line 1379], she replies: "Well! What of that? In what do they excel me?" Chaouli (n. 15 above), 137, comments on Penthesilea's utter madness and megalomania in this scene, and Volker Nölle, Heinrich von Kleist: Niederstiegs- und Aufstiegsszenarien: Versuch einer Phantasmata- und ModellAnalyse (Berlin: Erich Schmidt, 1997), 67, uses the German word, "Größenwahn." 
death wish, and just as Penthesilea needs to reconcile all her decisions with the wishes of her mother, the prince wants to believe that his execution will concur not only with his duty to the fatherland, but also with the explicit wishes of the Elector, his foster father, toward whom his feelings are just as ambiguous as Penthsilea's toward her mother Otrere. In the end, however, his ambitions are crushed again: at the last moment the Elector stops the firing squad, having decided that a mock execution is sufficient to re-assert the authority of the state and to re-educate the prince for good. The play's conclusion is particularly moving, as it reveals Kleist's own dilemma: while his heart is obviously with his protagonist, he does his best to take the side of the Elector who, driven by his raison d'état, has taken drastic measures to deflate the prince's ambitious dreams of fame and glory. The play ends with the relieved bystanders laughing heartily at the prince's bewilderment at his unexpected pardon, but for all Kleist's efforts to the contrary, the apparent happy end looks bound to turn into tragedy once the curtain falls: cheated not only of eternal glory, but also of the opportunity indirectly to commit suicide, the prince will hardly be able to laugh with the others, but will either have to endure what will seem to him an empty and worthless life, or to look for other means of ending his life, including a completely new moral justification of his suicide.

This connection between the two plays suggests that Prince Frederick of Homburg was written to strengthen Kleist's resistance to his own suicidal tendencies. Ironically, the play's completion left Kleist just as frustrated in his ambition as his protagonist, as the princes of Prussia to whom a copy of the play was delivered by Marie von Kleist did not even wish to acknowledge its receipt, apparently regarding the hero's attitude towards death as unmanly and unworthy of a Prussian officer. Obstructed one last time in his artistic as well as in his political ambitions, and with his financial means exhausted, ${ }^{46}$ Kleist saw suicide as the only way out. But

\footnotetext{
${ }^{46}$ Kleist's plays The Battle of Hermann and Prince Friedrich of Homburg were meant to make the Germans ready and fit for war against Napoleon, as was his local newspaper, Berliner Abendblätter, which he edited from October 1810. In March 1811 he had to discontinue its publication as an indirect result of political censorship. Faced with bankruptcy, he applied to the Prussian Chancellor for the position as editor of a provincial official gazette and, when the application was turned down, wrote his petition to the King, complaining about the Chancellor's
} 
after having worked hard in Prince Frederick of Homburg to destroy the moral justification of suicide which he had constructed in Penthesilea, he had no strength left to think of a new and better justification, and so fell back on the outward pattern of the suicide of his tragic character, Penthesilea.

It is to Kleist's credit that, unlike Penthesilea, he blamed his failure in life on nobody but himself: "The fact of the matter is that there was no help for me available in this world." 47 The wording of this statement, written on the morning of his death in his farewell letter to his sister Ulrike, suggests that it had been his idealistic objectives which had doomed his life to failure. From this perspective, the above assessment of Kleist's suicide as a pathetic parody of Penthesilea needs to be reversed: it is the play which falls short of real life, and thus of the main objective of tragedy pursued by his successors, Georg Büchner, Henrik Ibsen and Gerhart Hauptmann. Yet Penthesilea is anything but a celebration of lofty idealism: Kleist's relentless probing into the relationship between murder and suicide, psychopathology and barbarity, deception and self-deception already anticipates the development which nineteenth-century literary drama would take in Germany, and no tragedy by Büchner, Ibsen, or Hauptmann comes closer to foreshadowing Hitler's pseudo-heroic and pseudo-tragic perversion of idealism into inhumanity than Penthesilea.

unwillingness to compensate him for his financial loss from the discontinuation of the Berliner Abendblätter. (See Briefe von und an Heinrich von Kleist [n. 30 above], 489-90 and 1038-39.)

${ }^{47}$ Briefe von und an Heinrich von Kleist (n. 30 above), 513. 